\title{
La Barcarola: Barca de la Vida
}

1. Pablo Neruda es esencialmente un poeta biogrático: nada, prácticamente nada, que haya dejado una marca en él y que después se convirtiera en cicatriz, nada que ardiendo haya purificado su poesía, escapa a su constante vigilancia y estricto sentido de conducta. Despacioso, metódicamente acucioso, penetrante, Neruda examina lentamente las cosas y las gentes a su alrededor. Recibe vastas influencias, abstractas y concretas, $y$ las absorbe como un campo abierto en la noche; en apariencia pasivo y sin discriminar, pero en verdad profundamente consciente de matices y detalles, cuidadoso de no causar daños cuando llega el momento de almacenar pequeños y grandes tesoros. Recuerda los libros que leyó, las enseñanzas aprendidas de amigos y enemigos. En su discurso de aceptación del Premio Nobel Neruda nombró a un solo poeta: Rimbaud. Renegociando su deuda literaria externa en Nueva York reconoció con gran dignidad a Walt Whitman. Así como tiene patentes los lentos atardeceres de Maruri, los pétalos que caían en la acera, las dos colegialas y los veinte poemas, así recuerda también al Yeats y al Blake que leyó en inglés, al Apollinaire que leyó en francés. ¡Cómo va a olvidar a Villamediana y a Quevedo!

Todas sus lecturas y lugares donde vivió están registrados minuciosamente en su poesía, algunos claramente, otros con la celosa imprecisión del otro Pablo, el retratista Picasso. En consecuencia, no es mucho el es. fuerzo que han de desplegar críticos e historiadores para desentrañar raíces en la obra de Neruda: allí están las enredadas lenguas subterráneas de Góngora, las aéreas hojas de los Cancioneros, las retorcidas ramas de Blake, los oscuros injertos de Joyce, la precisión podada de Eliot, las ramas caídas de Mayakovski, Swinburne y Crane.

Presentándolo en la comida del aniversario del PEN Club en 1972 en Nueva York, Arthur Miller dijo que Neruda, padre de la literatura latinoamericana, era un árbol que, al dejar caer sus semillas, hace crecer 
otros árboles a su alrededor. De manera que Neruda es un bosque. En compañía de estos árboles que se llaman Eluard, Aragon, Alberti, Gingsberg, Bly, Neruda sigue creciendo, generando sombra, refugio, savia. Pero, vamos con cuidado. Habría que ser ciego para no advertir las diferencias sutiles pero marcadas que convierten la poesía de Neruda en un rito personal, intransferible. Antes de entrar al tema que me preocupa ahora quisiera mencionar dos factores decisivos de tal peculiaridad: uno relacionado al lenguaje, el otro referente a la realidad que da vida a este lenguaje.

Se ha hecho costumbre repetir la fórmula de "enumeración caótica" de Spitzer cada vez que se alude al modo de Neruda de catalogar al mundo en su proceso de desintegración y ruina. Sin embargo, es obvio que un poeta como Neruda, que se proyecta sobre el mundo desde un estado de alienación y ensimismamiento, tendrá sumo cuidado en la desordenación de sus imágenes, pues no debe perderse en su realidad interior y también en su realidad exterior. El punto de control inteligente a que se refería Santayana ${ }^{1}$ al distinguir el acto de alta creación poética de la simple explosión eufórica, jamás desaparece en el proceso de elaboración de Neruda. Es lo que revela su sentido de navegación mortal, lo que mantiene su sistema en pie durante el naufragio. Considerada su poesía desde este punto de vista -el lenguaje como instrumento de salvación personal en medio del caos- resulta que las enumeraciones de Neruda no son verdaderamente tales, sino eslabones de un movimiento narrativo. Neruda narra y refleja. Sus imágenes funcionan como espejos revolventes que hacen reflejos de reflejos. Tomando a Neruda como una especie de flechero errático, Alonso confundió los fragmentos veloces del vuelo de la flecha con disparos fallidos, sin notar que cada imagen de Neruda es parte de la distancia toda que recorre la flecha, y que sus innumerables flechazos son partes de la flecha única, ésa que, al fin, pega en la fama.

Sistema es éste que le permite al poeta ajustar el movimiento de sus imágenes a la mecánica del ralentisseur, no de otro modo podría reproducir fehacientemente el colosal colapso de cuerpos, cosas y ciudades en los tiempos que le ha tocado vivir. Cada verso es un espejo de la desintegración anterior y un reflejo de la que sigue; cada palabra, a su vez, es un minúsculo espejo cara a cara con la reconstrucción levantada en otro espejo, es decir, en otra palabra. El poema viene a ser, entonces, una casa de espejos donde la división del mundo en imágenes es real y verdadera.

Nada de fortuito hay en la ordenación de esta estructura de imágenes y poco de simbólico en el movimiento generado por las palabras. Ante

1 Cf. Interpretations of Poetry and Religion. New York: Charles Scribner's Sons, 1921. 
nosotros van levantándose inmensas instantáneas tomadas por una cámara borrosa que todo lo convierte en montage. Un largo y minucioso examen de poemas como "Arte poética" y "Walking around", por ejemplo, revela en las múltiples exposiciones la sombría nitidez de la soledad $y$ angustia que siente el poeta entre gentes y cosas totalmente comunes que nosotros mismos sentimos extrañas y crueles.

El segundo factor a que aludo se relaciona con un modo peculiar de interpretar la realidad inmediata. Un hombre como Neruda que ama sensualmente las cosas materiales y sensualmente se acerca a los seres humanos, se diferencia de la mayor parte de los poetas de hoy en que rehusa forzar la apariencia externa de la materia para convertirla en molde de alusiones simbólicas. Maneja las cosas sin alterar esencialmente su forma natural y así extrae de ellas su poder de trascendencia dentro de la realidad, desdeñoso de las posibilidades de conferirles una vida equívoca en proyecciones espirituales. Sin embargo, captando toda la realidad de un modo directo, Neruda logra que las cosas y los seres reverberen en su poesía, como si ardieran por dentro, y que se multipliquen produciendo así una impresión de metafísica grandeza. Solamente una impresión.

Neruda les ha enseñado a los poetas de hoy a tomar la realidad sin subterfugios y a no jugat con mensajes ambiguos y trucos de magia y hechicería. Examina el mundo como un relojero con su vidrio de aumento en el ojo. Prueba lo que ve. Si le gusta, lo devora. Es su manera de poseer lo real. Este es el secreto de las Odas elementales: no la compren. sión de la realidad, sino el goce y la consumación de la vida. A una sociedad enroscada en sofismas y entelequias, que pide poetas oscuros, caprichosos y volátiles, Neruda le da poemas como casas, como ciruelas, como botes y como árboles, con toda la engañosa simplicidad de las cosas hechas por el hombre y la naturaleza. En este sentido Neruda es un creador, no el pequeño dios de que hablaba Huidobro, sino un poeta cuya llave para asomarse a los secretos es el lenguaje: directas, concretas y barrocas palabras. ¿Me contradigo al decir "barrocas"? No. Unos ven las cosas con más y otros con menos detalles. Neruda ve también los seres humanos que fueron sus dueños y quedaron en ellas. Como otros buenos poetas. Esto es de suma importancia para su poesía materialista: es la carga emotiva que la acciona, su única fuerza espiritual reconocible y válida. Neruda, en consecuencia, es un poeta de cosas y fantasmas materiales, un hombre que incesantemente recorre los puentes-cubiertos del pasado y sabe cómo se las ingenia la vida para aparecer como un eterno presente. Ahora bien, nombré a Picasso pensando en su fragmentación de la realidad, pero también en sus períodos que se suceden con fluidez y po- 
tencia; debo añadir que los ciclos públicamente reconocidos en las miles de páginas escritas por Neruda, como los períodos de Picasso, no son pedazos colgados en el tiempo, detcnidos y desconexos. Son partes indivisibles de un fluir, olas que se suceden y entretapan. Neruda, autobiográfico, persistente, poeta hacia atrás y hacia adelante, de pie sobre una correa eléctrica que no acabará de pasar, que descubrió temprano en su vida la conjunción plena de sus palabras y sus actos, cuyo sentido profético se reveló en la coincidencia esencial de cada ciclo poético suyo con cada una de sus dramáticas crisis personales, no termina en Residencia en la tierra, ni en el Canto general, ni en las Odas elementales: los viejos ciclos vuelven con sus temas y sus tonos, un tanto irreconocibles porque las voces no son ni serán nunca ya las del año veinte ni del treinta ni del cuarenta, tapados por medio siglo. Entonces uno concluye que los Veinte poemas de amor están metidos en los Versos del capitán con pasión un poco desatentada y ansiedad hogareña, conscientes ahora de la colina herida, pensando que si la mujer fue una geografía, las mujeres, como islas, desaparecen pero vuelven a levantar cabeza en los cataclismos, y los Versos, a su vez, son un Neruda ya macizo, sobrio y sonoro en los Cien sonetos de amor, pues la configuración del endecasílabo se plegó en sí misma, el sonido es de maderas o de cueros y el abrazo del poeta se cerró en una mujer, como puerta golpeada por el viento y por los años, y los Cien sonetos siguen sonando en el Memorial de Isla Negra porque la familia es ahora historia y requiere la garantía de un recuento pormenorizado.

Mientras tanto los libros nacen y crecen. El poeta sigue el ritmo creador de las olas. Se le viene a la memoria una canción que murió y renació con ei siglo y en cuyos vaivenes han valseado guerras y revoluciones, terremotos y sequías, nacimientos y muertes, separaciones y encuentros, guerreros, mártires y héroes. Descubre, pues, una forma nueva de indicar su paso por el mundo. Esta forma adquiere un repentino significado porque otros poetas de la antigüedad clásica y del medioevo ya la conocieron y la usaron con sentido diferente. ${ }^{2}$ Neruda vuelve a ser el

2 El principal propósito de este trabajo no es relacionar directamente la temática y la forma de La barcarola con las antiguas alegorias de La barca del estado, La barca de la muerte y Das Narrenscbiff. No obstante, pienso que Neruda, acaso intuitivamente, entra aquí de lleno a una tradición literaria cuya premisa esencial es la simple y gráfica imagen de la humanidad viajando en una barca hacia la eternidad. Para Neruda la humanidad vive y trasciende en la persona de los dos amantes. La imagen del Narrenscbiff fue inmortalizada por Sebastian Brant (1458?1521) en Stultifera Navis (1494). Su alegoría en verso ha ejercido una vasta influencia a través de los siglos, como lo comprueban las numerosas ediciones en alemán, y las traducciones al inglés, al francés y al ruso, además de imitaciones y adaptaciones. La barcarola de Neruda navega, pues, por aguas conocidas. Pero 
eslabón que une las edades de la poesía: atento aún al "ruido de un día que arde con sacrificio" y al "golpe de objetos" para el cual encuentra respuesta y al "nombre confuso" que empieza a aclararse como un vasto cielo sobre Isla Negra.

2. La barcarola: se compone de una introducción y doce episodios. A cada episodio sigue una glosa recordatoria o un poema íntimamente, a veces secretamente, vinculado a la época de los hechos que se narran. Como en toda poesía autobiográfica, seres y cosas funcionan como signos. $A$ veces los signos se autodefinen a través de la repetición, o entregan ellos mismos sus claves. A veces las personas aparecen con su verdadero nombre -Rubén Azócar, Rubén Darío, Lord Cochrane, Artigas-, o bien con la cara que les da el poeta haciendo de la leyenda un héroe - es el caso de Joaquín Murieta-, o de una mujer el otro rostro del poeta: Matilde. También las ciudades tienen la forma, las estaciones, los sonidos, las horas, que el paso de Neruda encuentra mientras busca el sitial de la pasión y el camino hacia un regreso donde no termina nada, sino empieza nuevamente la barcarola: canción de gondolero, con ritmo de seis por ocho, redonda, cantada a lo largo de canales sin principio, sin fin, sin dirección, excepto la del remo en el acto de quebrar la luz sobre las aguas turbias. Praga, Budapest, París, Moscú, Santos, Montevideo, Valparaíso, son las ciudades. Finalmente, un tercer grupo de caras sirve de nexo a las vidas del poeta: las máscaras marinas, las señoras y doncellas de madera que enjuagan sus vivos colores en remotos huracanes y se secan en la rosa de los vientos, La Medusa, La María Celeste, de perdurables ojos de vidrio o de palo y oscuros pezones y cabelleras de oro pintado, presidiendo en su vuelo detenido las sombras, los libros y los globos terráqueos de Neruda en su casa de Isla Negra.

3. La introducción: comienza la barcarola como toda barcarola debe empezar,

Amante, te amo y me amas y te amo

un hombre corpulento y suave, guerrero cansado, bota sus viejos trajes, sus anillos, sus bastones, toma por la cintura a una pequeña mujer hecha

su rumbo no es el de Brant ni el de Gil Vicente (Trilogía de las barcas): sus amantes van en busca de la vida.

Sobre la copiosa bibliografía relacionada con este tema y la influencia de Brant, veanse: The Ship of Fools, translation by Edwin H. Zeydel, New York: Dover Publications Inc., 1944; y Sebastian Brant, by Edwin H. Zeydel, Twayne Publishers Inc., New York, 1967. 
de sol, y navegan. La estación del año pertenece a los amantes, "la tempestad de septiembre - cayó con su hierro oxidado sobre tu cabeza", los dones y aromas son restituidos, la guitarra de ámbar es Matilde, la chillaneja; los quebrantos de amor son fulgores que despide el invierno. Sonoros versos, lentos, con árboles y casas, ríos, arena, espumas, trigo, en grupos de doce, quince, siete sílabas, aparecen al comienzo de $L_{a}$ barcarola interrogando llenos de júbilo y asombro. La canción revela, entonces, de a poco, el camino recorrido por los amantes. No ha sido una fácil jornada. Una búsqueda a través de siete fronteras, ecos de calles extrañas, nieve cerrando el paso, preceden al encuentro. El amor es violenta turbación y combate, un súbito resplandor, conmoción prolongada, lenta pausa de un fuego que halla su camino en despaciosa lava. Los términos del encuentro son duros: dientes, besos, espadas, ortigas. La anticipación está llena de sombras, pero también de rosales. Se habla de heridas e incertidumbre, de escondites y lágrimas, ira también y desesperación, nombres a los cuales el poeta les da forma de puettas cerradas y ciego movimiento, entradas y salidas, apariencias de actos finales. Las múltiples heridas se han compartido. En alguna parte queda la imagen expectante de una mujer que amó al poeta y ahora tiene "una lágrima ronca en los párpados".

El gondolero está cantando sinsabores. Aparece un capitán en escena, cubierto el rostro con una máscara negra, y canta versos "fugaces y duros, floridos y amargos". Estos versos anónimos que hablan de un amor secreto saltaron como un volador de luces desde la Argentina y en ellos las gentes vieron la rúbrica invisible de Neruda. La canción del capitán dividió a los amigos. Una canción dentro de una canción, como quien dice una vida dentro de una vida, explica marginalmente la crisis de una poesía al borde de una historia que se acaba y otra que comienza.

El "muro arañado" debe abandonarse. La miel será para los amantes. El pozo clandestino queda ardiendo en las tinieblas. Lo que fue "impura miseria", lo que se buscaba "por agua y por fuego - por tierra y por luna, por aire y por hierro, por sangre y por ira" siempre estuvo allí al alcance de la mano. Vuela el antifaz. Las calles de Roma florecen, el amor reconocido y pasional enseña "a mirar el mundo". Cambian, pues, los términos del amor $\mathrm{y}$, con ellos, los nombres de los amantes. Ahora se llaman Capri. La barcarola se desliza por aguas puras, el amor es "torre invisible que tiembla en el humo", es almendra, zafiro, cola estrellada, miel, por donde navegan una estatua de proa desnuda, ella, y un ciclón de hombre colmándola. 
La descripción de Capri se descompone en elementos de color y textura - grietas, musgo, muros-, de sonido - cítara, cuerda, voz-, y signos de soledad: enredaderas, rocío, fragante recinto, alturas. Es una disposición de objetos para situar entre ellos a la mujer que los anima, representa y trasciende. El poema "Tú entre los que parecían extraños" se convierte en declaración de identidad y unidad esencial, fórmula poética de una ecuación cuyos factores son mujer-greda-patriapueblo-humanidad. Matilde representa a la mujer-tierra, parecida al vino, al trigo, al pan, ánfora araucana que descubre su igual (identidad) en el cántaro etrusco; en ella Quinchamalí y Pompeya adquieren la forma única; los nombres no tienen nombre, "son los misterios del pueblo ser uno y ser todos". La mujer-mundo hace cantar sus caderas. Sombra, música, y barro son el amor, es decir, los materiales que el poeta sopla $y$ transforma en el movimiento de la vida.

Ahora bien, este movimiento tiene sus señales, su sentido secreto y una clara epifanía. Las estaciones van llamándose sueños, nostalgia, destierro, un poco más nítidamente "dulce patria" $y$, con mayor relieve, resurrecciones, poderes, cantos, barco. El sentido va surgiendo lentamen. te, al modo de un Cántico espiritual que, a través de la amada, descubriese no una luz, sino una tierra, y en la tierra la significación del amor. "Tal vez el amor restituye un cristal quebrantado en el fondo del ser, una sal esparcida y perdida". El olvidado despierta de pronto con el beso que, como un relámpago, abre de par en par la memoria. En el mar se navega de vuelta a ciertas raíces que son lugares, cosas, gentes, nombres redescubiertos, cifras que esclarecen el significado de quienes fueron padres, amigos, amantes, en el olvido, rostros desaparecidos en nuevos rostros que se inclinan a mirarnos. Las calles recuperan sus nombres, los pueblos se llaman Rengo, Rancagua, Renaico, Loncoche, Pillalelbún, el campo y el humo reaparecen, las islas, el viento, la nieve, el lodo, el sonido de una campana en el agua dan realidad al lago Llanquihue; todo adquiere forma definida: una torre, un arco, la pareja que lee novelas heroicas después de comida, los trenes desviándose en la madrugada, los ríos oscuros, los bosques, y en su forma reconquistada cierran la dialéctica triste del hombre que atravesó el umbral de una casa en tinieblas y ahora vuelve a salir a la luz.

Es este instante dramático y lúcido en que algo clausurado se abre y alguien detenido se echa a caminar, que celebra la barcarola: sombra y música, barro y luz, letargo y corriente, ausencia y presencia "como si el día y la noche cortaran su nudo mostrando entreabierta - la puerta que une y separa a la luz de la sombra". Así redescubre el poeta sus 
propias raíces en un amor que el remero lleva de sus turbios canales al agua clara de una memoria súbitamente abierta a importantes recuerdos.

Pablo y Matilde regresan a la patria, es decir, descubren un pais que ahora une todos sus caminos, un país que se amarra, se clava, se enviga, se techa, se llena de domésticos seres y vuelve a ser casa: La Chascona, La Sebastiana, Isla Negra. Ambos sobrevivieron la transición indicada aquí por imágenes que van y vuelven de la naturaleza al hombre, del hombre a la mujer, de la mujer a la naturaleza. Matilde es el fondo del lago, por ella se da nombre a las cosas, es la raíz del canto y la puerta entreabierta que comanda luz y sombra. El amor restituye los poderes, reúne los pedazos del cristal roto y junta la sal; es el equilibrio de una amapola o una abeja, el secreto orden que mantiene girando los pequeños reinos. En suma: a un amante tardío la pasión llega con la fuerza clásica de una revelación mitológica. El amor es saber tanto como creer, reemplazar un reino de estatuas de sal por una compañía gesticulante de amantes y cómplices que ordenan el mundo al vaivén de la barcarola, en tiempo de posesión marcado por un reloj sin minuteros ni números: la esfera blanca donde el tiempo vuelve a levantar su tienda.

La parte última de esta introducción es un canto a las fuerzas que juntas reconstruven el mundo: la amistad identificada con el amor, corriente continua que permite a las maderas unirse con los clavos, a las flores con el agua, a las raíces con los astros, a la arena con la lluvia, con el horno y el trigo, al mar con los cerros, y a los hombres con países distantes que, a su vez, unen sus puentes, carreteras y ciudades, en un solo movimiento aprendido en la barca de los amantes ocupados.

4. El Primer Episodio trata de un suceso tradicional: "Terremöto en Chile". No es una narración sino, más bien, una noticia que llega a través del firmamento hasta la barcarola. La repentina noticia viene con el ruido sordo y subterráneo del primer sacudón, el tañido incontrolable de las campanas, el choque de los cristales, la oscilación de las lámparas, y luego un remezón ondulante que bota cuadros, libros, sillas y botellas, preparación del segundo remezón que se confunde con la carrera de pies desnudos en la noche y el sonido seco de las marquesinas que se desploman, los muros que se parten, algunos gritos pero más rezos, golpes en el pecho de ancianas hincadas y la explosión de cañerías y grifos que inundan los pisos mientras flotan escaleras abajo zapatos, sombreros, cartas y cortinas. Después sigue temblando el mundo, 
las luces se han apagado, una polvareda se levanta sobre las plazas, continúan cayendo vidrios y algunas puertas no pueden abrirse.

Para el poeta que piensa en su casa, en su gente, el cataclismo es un caballo que "patea el planeta" y deja su marca de herradura en los pobres de Chile. Escombros, viento, hospitales, desiertos, volcanes, silencio, son los huecos por donde cae la patria como un costal abierto de súbito. No abstante, un lado del cataclismo crea el otro, como una sombra que, al pasar, revela la luz que la hizo. El Episodio se transforma en un canto a Chile y a los chilenos. País-materia cuya excelencia está en su cordillera, sus viñas azules, su vino, sus estrellas que huelen a jazmín y a nieve, sus pescados y cereales, sus metales, maderas y toneles. El poeta nombra cincuenta apellidos de cepa, hermanos de suaves costumbres, trabajadores de invierno y verano. "En medio del mar los llamo y me llamo: el que cae me cae, el herido me hiere, el que muere me mata".

País hecho de cosas duele más cuando lo bota un terremoto. Netuda expresa nuestra alarma ancestral ante un enemigo que nunca hemos visto y que insiste en desplomat nuestras paredes y en quebrarnos los muclles, al mismo tiempo que detiene a los vecinos con golpes de teja en la cabeza. El chileno marca el pasa del tiempo con la enormidad de su tragedia. Otros dirán "el año del Centenario" o "el año de la Independencia", nosotros decimos "el año del terremoto". La barcarola sigue para afirmar la indestructibilidad del amor, la impotencia del adversario artero, la voluntad de sobrevivir de los invulnerables.

5. "Serenata en Paris" es el Segundo Episodio y el primero donde se canta a una ciudad en la imagen de ciertos amigos, ciertos difuntos, techos, vitrinas, panaderías, humo, espejo, río, trenes, iglesias y otoños. En conjunto, es la imagen de una permanencia que se afirma tanto en estructuras materiales como en la inefable voluntad de ser de una ciudad visible a través de sus fantasmas. Una calle, mesas en la acera; de noche, los melenudos se aman los unos sobre los ottos; escucho a Neruda, observo los techos torcidos en el pequeño hotel de la Rue Huchette; hay manzanas junto a la ventana; Matilde se asoma; en el boulevard se mueven las hojas del verano, límpianse las calles y sólo queda un eco de los escritorios que caen desde una pensión de estudiantes. Ese amor de dos espesas melenas y pantalones ceñidos, metidos uno adentro del otro sin sexo reconocible, perturba con su silencio industrioso. Pero existe una paz también y significa supervivencia. París renace "de guerra y basura, de besos y sangre - como si en cada hora millones de 
adioses que parten - y de ojos que llegan" la fueran fundando. 'La estrecha calle va recibiendo en la soledad de este amanecer tranquilo un río de gentes antiguas y viajeros extraños. Un centro que deja girar la muerte para dar vueltas al amor. Los amigos van y vienen movidos por una barcarola repetida en viejos acordeones. Aragon, Elsa, Vallejo, Crevel. "Se me olvidan los nombres del baile", dice el poeta. Con la voz del novecientos vienen metáforas ultraístas, restos de un baile ya olvidado:

duermen las viñas y el vino en las cubas prepara la salida del sol, profesor de francés en el cielo.

Amor mío, en la Isla de Saint Louis se ha escondido el otoño como un oso de circo, sonámbulo, coronado por cascabeles.

Acaso esa melodía de antaño da la verdadera cara de una ciudad que, en buenas cuentas, parece hecha de demasiados olvidos. Porque la ciudad luz es también de ceniza, "una muchedumbre de pétalos que arden sin rumbo en la noche". Esos pétalos y esa ceniza, como una inesperada iglesia "que muestra sus graves costillas", son reiteraciones de un triste, pero tranquilo, cansancio. En París yacen los amantes:

tendidos, caídos al sueño, siguiendo el inmóvil camino, con un día de más o de menos que agregó a tu vestuario un fulgor de oro inútil que, sin duda, o tal vez, es la vida.

La barcarola sigue y para en Chile: es azul regresar, altí está el océano, la espuma, la nieve; y es eterno comer, es decir, volver a encontrar las esencias de la tierra en sus frutos.

"Estoy lejos" es un extenso poema en que el tiempo, la soledad, el amor y el arte de la poesía juegan un clato contrapunto autobiográfico. Claro en la intención, ya que los términos siguen siendo cifras para una clave que Neruda guarda celosamente.

La soledad de la Patagonia es tiempo, queda dicho en los dos primeros versos y se representa con el paso de rebaños-nubes por el cielo, el olor a campana (tiempo) del espacio (tierra sin habitaciones), el transcurrir de la luna (tiempo) "amarrada al caballo más lento del cie10" (tiempo y espacio). La soledad-tiempo pierde sentido inmediato al aparecer Matilde. La luna va en ella, con ella mueve "su círculo de oro". Matilde es centro. Diversas cosas, pero especialmente animales, 
ayudan a fijar este centro: "el zorro de pies invisibles", "el postrer colibri" ése "que encendió su pequeño reloj de turquesa en el brazo de las soledades", además de avestruces y caballos. En última instancia, sin embargo, es la tierra sola que da la medida del cambio en la relación de los amantes y en el lugar que ocupan en el mundo. El amor acaba con las dudas, las soledades y la muerte. Reina la primavera y reina Matilde con suavidad y rectitud. Curiosamente, producido el milagro, La barcarola se vuelve sobre sí misma y se hace reflejo de su propia poesía:

Yo cambié tantas veces de sol y de arte poética.

¿Qué ha pasado? Neruda aún servía de ejemplo "en cuadernos de melancolia" (Veinte poemas, Residencia en la tierra), cuando ya lo inscriben "en los nuevos catálogos de los optimistas". Los críticos lo estudian como aduaneros, lo declaran oscuro, lo declaran claro, lo denuncian a la policía por progresista, alguien se dedica a ser enemigo suyo de profesión en todos los idiomas. Neruda, como un pájaro obstinado e inalcanzable, responde cantando.

Esto tiene que ver con el año en que regresa a Chile de tal viaje. La barcarola no nombra a los difíciles enemigos. Los deja atrás y vuelve a hacer sonar los nombres del país: nieve, bosques, arena, océano. El vocabulario luce con una claridad renovada. Nueva vida, dice el poeta, nuevo amor, nueva poesía:

La borrasca que enciende la espuma coronando el cenit del oleaje me ha enseñado a limpiar las oscuras herramientas de mi desvarío.

El envío, quiero decir el cogollo, es una tierna canción de amor, lírica, elocuente, alzada y sonora, un bello nudo de palabras que indican el tiempo, la pasión, el país y las letras, unidas en la imagen final al verano, el trigo y la Araucanía.

6. Sigamos con los lugares, el Quinto Episodio se llama "Las cam. panas de Rusia". No es exactamente un lugar que canta La barcarold, sino el pueblo que se reconoce en el tañir de sus campanas. Rusia es una infinita noche, una estepa vacía; el poeta, sólo, escucha "una voz, otra voz, o el total de las voces del mundo", sonido profundo y lento, que sube y baja, y en su movimiento despierta imágenes de guerra (casas quemadas, calles con barro y nieve, huesos quemados, lágrimas, incen. dios) y, sobre la visión del pasado feudal (un zar coronado por "medio. 
evales herreros", siervos con el olor y el vapor del ganado rezando en la iglesia) acelera el vaivén de las campanas y suena "el canto común" de la revolución de noviembre. Las campanas tocan por "la escuela florida" y por el nuevo hogar. Neruda es una campana que "canta la fiesta del mundo":

$Y$ cuanto acontece recojo como una campana y devuelvo a la vida el grito y el canto de los campanarios de la primavera.

El tañir de las campanas se transforma en una sola gran metáfora de su poesía: alli están las sombrías campanas de la guerra, el doblar heroico de la revolución, el revoloteo de los sonidos nupciales, el llanto, el baile, la canción, todo lo que sonó en sus manos haciendo el trayecto de la estepa-soledad hasta la luminosa conciencia de su fraternidad universal. Las campanas, sustantivo sólido, constante a través de su poesía, son en La barcarola signos de un nuevo arte poético, reiteración de su fe en la poesía como aprendizaje de vida y comunión en los goces de la materia:

\section{cantemos campanas}

por la eternidad del amor, por el sol y la luna y el mar y la tierra y el hombre.

Sigue La barcarola con un comentario en clave sobre los más fieros enemigos del pocta. Acusaciones, defensas, denuncias y amenazantes augurios, todo en un denso secreto. Es de suponer que se refiere a la jauria literaria y política que lo persiguió en su patria. Su principal defensa es la poesía igualada a "la bondad". Mientras más suenan los gritos de combate y con mayor revuelo saltan "los clavos del odio", más firme es su confianza en los poderes de su arte y la riqueza de la realidad en que se nutre. Probará la sal, el fuego, el "arroz negro", signos de maledicencia y odio, pero se salvará en la poesía, envuelto en un otoño millonario:

me retribuye el Otoño con tanto dinero amarillo que lloro de puro cantor derramando mi canto en el viento.

7. "Santos revisitado (1927-1967)", Noveno Episodio, constata lo que hacen cuarenta años de crecimiento industrial a una ciudad distraida. El poeta conoció un pueblo cuyos términos de denominación tropical eran: puerto selvático ("olía como una axila"), café, Pelé, banana, 
estiércol de oro, rabiosa lluvia caliente, enfermedad del mundo. El consorcio internacional se hace cargo de Santos y le pone algunas cosas que suenan ultraístas: frigoríficos que parecen catedrales, edificios que son como "juegos de dados de dioses". Espero, dice el poeta, "que revientes un día de alimentos, de sacos masticados - y de eterno sudor de hombres que ya murieron - y fueron reemplazados para seguir sudando". Luego, pide perdón:

perdonen algún día si no vi el crecimiento de los edificios porque estaba mirando crecer un árbol, perdón.

Todo Brasil, Latinoamérica, le va creciendo a la tierra como un Tercer Saco hinchado y violento que rebasa sus costuras; Brasil más rápidamente, con estirón y humedad tropicales. Crecimiento desigual y monstruoso. Pidamos perdón y tiempo, dice el poeta, para alguna vez ajustarle las medidas y comprobar si los edificios en realidad crecen como los árboles.

Después de esta visita a Santos La barcarola sigue con un canto de amor a Matilde.

8. Los personajes: Que fuera Rubén Azócar el béroe del Tercer Episodio "Corona del archipiélago" no es de extrañar, pues fue amigo y compañero leal del poeta y su defensor a través de años de guerras literarias. "Nunca he visto otro árbol como éste", dice Neruda. Yo tam. poco, porque Rubén Azócar, el autor de Gente en la isla, echó y dejó raíces por todo Chile. Lleno de cicatrices y rayado "el rostro de Azócar, de piedra y de viento, de ley machacada" oscuro y luminoso, a la vez, "estatura de cuero y de pelo", hablaba con voz muy ronca y pronunciaba eses de maestro de escuela y patio asoleado y bancas descoloridas donde los niños dibujaban iniciales y corazones con cortaplumas; "tronco quemado en la selva", Azócar convivió con Neruda años de juveniles duelos $y$, después, hombres ya, años de dura política, haciéndose fuertes ambos en la Alianza de Intelectuales y en la Sociedad de Escritores, juntando los poderes de la palabra y de la amistad, sacando la cara uno por el otro y poniendo la poesía donde ponían la bala. La "Corona del archipiélago" es para un camarada cuya muerte llega, como esa otra de Rojas Jiménez, en un pedazo de papel, desde la patria remota. Neruda no canta aquí en versos que vienen volando en formación estricta y pareja, sino más bien, y pensando en Azócar, en versos amplios, narrativos, abiertos. Cada recuerdo lleva consigo un gesto de Azócar: su bondad 
"ojos dormidos", la pobreza "cejas de árbol", la cólera "cejas pobladas por árboles negros", el vigor "tu cabeza de rey araucano", sus desengaños "la tristeza en tus ojos antiguos". Azócar fue hombre de acción y devoción. Fuerte, de pequeña estatura, dirigió la SECH tosiendo, fumando, observando con ojos claros y pacientes. Neruda recuerda algunas cosas en este poema que todos los amigos de Azócar también recordamos. En la estrofa que empieza "El paseaba en Boroa, en Temuco..." se alude a un poeta que fue el enemigo más encarnizado de Neruda en Chile; en las líneas que dicen "Ya se sabe que un día de Cuba..." se refiere a una pantomima con que Azócar hacía reír a sus amigos, disfrazándose de niño - marinero con los pantalones recogidos y una flor en la mano. Es este recuerdo que conduce al final del poema, el repentino estribillo de la cueca:

Tengo el As!, tengo el Dos!, tengo el Tres! Pero faltas hermano! Falta el rey que se fue para siempre con la risa y la rosa en la mano.

Neruda recrea la alegría de Azócar, maestro de buenos porotos, cebollas y tomates que recogía sin levantarse de su silla de paja en el huerto de Pedro de Valdivia, su casa del campanário rojo sin campanas, frente a la cordillera, novelista grueso y arrugado, envuelto en humo, hombre con mucha tempestad adentro y una dulzura y una bondad que fueron su mejor legado.

Es natural que, al seguir La barcarola, sea a base de recuerdos intimos, amarrados poderosamente a ciettos años decisivos. Pasa el tiempo en la imagen de la rosa que es transparencia, pompa, aroma veloz, vuelo, $y$ es también pasión: cae del sexo para terminar en tierra. Rosa shakespeareana envenenada por el tiempo. La defensa de la vida concierne al poeta quien comparte múltiples existencias y trasciende, sintiendo que es él quien lleva consigo el secreto de la sucesión de los días y los años, así como el movimiento del mar y de las estaciones. Vuelve la vieja imagen de Residencita en la tierra a representar ahora un sentido cósmico de la vida diaria:

Sin embargo este día que ardió y consumió su distancia dejó atrás sus sombríos orígenes...

Desaparecer es aparecer renovado, los dís del poeta son anillos que van uniendo la muerte al nacimiento, el júbilo de renacer a diario es la señal de la fe en la unidad central de todo lo que vive. Este poema encierra una de las más claras expresiones panteistas de Neruda. Dice: 
Yo duermo hecho de noche, hecho niño o naranja extinto y preñado del nuevo dictamen del día.

En esta identificación suya con la naturaleza el poeta busca imágenes que lo prolonguen en las cosas. Las campanas, sus viejas, constantes campanas, representan aquí la voz de la poesía, el acto gratuito del canto, comunicación sin otro vínculo que el sentimiento.

El amor llega así a convertirse en una manifestación del mundo en medio de signos panteístas; su más alto tono lo alcanza en "Sonata", donde la mujer es mitificada en un proceso de humanización del paisaje y los objetos que condicionan su belleza. Mujer-cántato, piedra del río, agua, peral, bosque, paloma, tarjeta del rocio, metal, abeja, ámbar, guitarra, y también mujer-greda: Una cadena ascendente de epitetos que culminan así:

oh cazuela de aceite y cebolla, vaporosa, olorosa, sabrosa, oh expulsada de la geometría por arte de nube y cadera, oh máquina de agua, oh reloj de pajarería, oh mi amorosa, mi negra, mi blanca, mi pluma, mi escoba, oh mi espada, mi pan y mi miel, mi canción, mi silencio, mi vida.

El proceso de identificación continúa en "La calle", poema que por su vocabulario y asociación surrealista de imágenes parece volver al ciclo de las Residencias. Reaparecen los zapatos, almacenes, cinematógrafos, sombreros, jabones, cacerolas, obispos, ferreterías, telojes, espejos, escopetas y sacos de las antiguas artes poéticas de Neruda. El amanecer y la noche y la luz del nuevo día son, después, voces que se concretan en el cuerpo de la mujer a su lado; amanece en ella, el lucero es ella, la tierra y las estrellas se suceden dentro de ella y de ella salen.

El poema se encierra, entonces, en la idealización de los dos polos, la mujer y la tierra, que asumen la significación de factores supremos de la unidad descubierta en el trance de oposiciones: vida-muerte-vida. Las términos son semejantes a los de las Odas y del Canto general. Chile vive en la grandeza de sus materiales y en la fuerza para resolver sus catástrofes geológicas. Cada término tiene, en consecuencia, una significación dialéctica. Nieve es luz y es avalancha, desiertos, mares, cordille. ras, son síntesis de poderes contrarios. El hombre pica la piedra de su soberanía y de su sepultura para renacer en la voz del poeta.

9. Fulgor y muerte de Joaquin Murieta, Cuarto Episodio, es un acto de resurrección, rescate de una imagen oscura y legendaria para 
levantarla agresiva y elocuentemente contra otra imagen en camino asimismo de hacerse tradicional: la del violento expansionismo norteamericano.

Recuerdo muy bien el periodo de gestación de este poema. En 1964 conversé con Neruda acerca de una novela mía sobre los chilenos del oro en la California de 1849. Estábamos en Concepción haciendo la campaña de Allende. Di a entender que en California había ocurrido una saga que nos comprometía a todos y que yo no dejaría el Oeste norteamericano sin descargar mi conciencia y pagar mi propia deuda. En 1964 nos encontramos en Berkeley. Neruda me contó que había escrito un poema sobre Joaquín Murieta y que Matilde, al escucharlo, opinó que, siendo una cantata, era evidentemente teatro. Neruda operó el rifacimento y nos leyó su obra a un grupo de amigos en Berkeley. Terminada la lectura, Neruda pidió opiniones. Algunas damas entusiastas se apresuraron a exclamar que se trataba de una pieza maestra. No era eso lo que deseaba oír Neruda. Me pareció más honesto decirle que no había aún una obra teatral, sino un libreto para que un andaz e imaginativo director lo convirtiera en espectkiculo, a la manera de algunas comedias heroicas del siglo de oro español. Recomendé a Bill Oliver que estaba en Chile dirigiendo el Marqués de Sade. Oliver regresó a los Estados Unidos, y Neruda le entregó el manuscrito a Pedro Otthus quien, como se sabe, lo convirtió en una brillante epopeya con elementos de ópera, comedia, zarzuela, pantomima y hasta ballet.

El poema mismo depende de ritmos heroicos, marciales, combinaciones métricas de once, dieciséis sílabas, para recrear la figura de $\mathrm{Mu}$ rieta desde sus dias de forty-niner hasta el asesinato de su esposa Teresa y su sangrienta venganza y martirologio. Murieta es el vengador, Robin Hood criollo, vestido "de luto y plata", galopando por los valles de California, castigando a los usurpadores, robando al gringo, protegiendo al mexicano y al chileno explotados. El vocabulario tiene lat dureza del gitanismo lorquiano. La cabeza de Murieta habla en romance y preside su propia mitificación, uniéndose a otras cabezas igualmente elocuentes de La arducana, por ejemplo, o del romancero americano de los siglos diecinueve y veinte. La cabeza se pregunta:

Pero ¿cómo sabrán los venideros entre la niebla la verdad desnuda?

De aquí a cien años pido, compañeros, que cante por mí Pablo Neruda. 
Así, pues, le canta Neruda sin prestar atención a los académicos de la historia que ofrecen pruebas de la nacionalidad mexicana de Murieta. Neruda captó en él la imagen colectiva de un pueblo que clamaba justicia y venganza. Sacó al noble bandido de los callejones y aleros de Virginia City y lo puso a galopar otra vez por el mundo. Se cumplió así el ciclo natural de las grandes gestas populares: el bandido crece en la leyenda $y$, en el romanceado idioma del poeta culto, se glorifica y entra a la epopeya.

La barcarola sigue con un merecido descanso: es el otoño, otoño de fábula, y el poeta reflexiona calmada, distraídamente sobre el edificio de papel que Matilde comparte con él: papel como pelo de peluquería, "follaje gastado y caído", hojas que no lo tentarán, revistas de embajada, primeros trinos de jóvenes poetisas, y otros papeles aludidos enigmáticamente en los que vuelca sus cosas "un coiffeur surrealista" innombrado. El papel los circunda y ahoga. Las pes, las eses y efes se agolpan en el papeleo de la aliteración:

la plebe de puros papeles prensados galopa

... .ensimisma, susurra y sepulta

...flores fogosas y desfiladeros.

Pero, desde tanta hoja en blanco se levanta, al fin, el mar del otoño y las huellas son las del paso del tiempo y su lenta destrucción. Algas, hierro mojado, ovarios, máscaras, gomas, tristes corales, hierven "en la orilla del mar", "la podredumbre menguante y creciente" resuelve en silencio este movimiento de lo que perece y lo que trasciende. El signo de la supervivencia tiene la forma de flecha: desde el mar se levanta la emigración de los pájaros; "progresan colgados al cielo, al rumor de este mar oxidado". El mundo se expresa en esta "linea impecable". El poema concluye con rápida alusión a un viaje y a cierta relación establecida hace años entre la poesía de Whitman y la de Neruda: ${ }^{3}$

Se dice o dijeron o dije que el bardo barbudo y arbóreo de Brooklin o Camden, el herido de la secesión divisoria, vivía tal vez en mí mismo. .

"Tal vez", decide Neruda, observando que no es el individuo quien, conscientemente, estira y amarra las raíces de la poesía a través del tiem. po, sino ellas mismas en un crecimiento continuo, colectivo, cósmico.

3 Cf. mi Walt Whitman en Hispanoamérica. México: Studium, 1954. 
10. "R. D.", Sexto Episodio, es el gran poema lírico de La barcarola y uno de los más altos que ha escrito Neruda en los últimos años. Consiste en armar un nítido diseño de imágenes que descansan en palabras claves para reconistruir la juventud de Darío en Chile, su brillante despertar en Azul. . . (1888), su triunfo en España, su decadencia y muerte. Además, $y$ esto es la coronación del poema, Neruda ofrece una defini. ción de la poesía de Darío concentrándola en un vocabulario críticamente medido y seleccionado. Las imágenes que le sirven para identificar a Darío en su período chileno funcionan alrededor de voces y frases como: esmirriado, aduanero, singular ruiseñor, delgado estudiante, largo gabán, bolsillos repletos de espejos y cisnes, abandonadas bodegas, almacenes, humo, invierno ("tenía el invierno el olor de una alfombra mojada por años de lluvia"). El Valparaíso de Darío fue sórdido, pero desde allí empezó a repicar su campanario. Neruda evoca un momento de inspiración repentina, un llamado, una visión:

Yo no he visto silencio en el mundo como el de aquel hombre [dormido, dormido y andando y cantando sin voz por las calles de [Valparaíso...

El silencio se rompe con un clamor poético barroco:

Oh clara! Oh delgada sonata! Oh cascada de clan cristalino! Surgió del idioma volando una ráfaga de alas de oro... Darío conquista los ateneos españoles:

Tembló Echegaray enfundando el paraguas de hierro

[enlozado...

...y por vez primera la estatua yacente de Jorge Manrique

[despierta. .

¿Qué ha hecho Datío? Responde Neruda: "Inaugura la lengua española". El Modernismo aparece aquí esquematizado en imágenes y clavado como en un herbario. En el comienzo fueron espejos y cisnes. Después, Darío lleva en su pecho "un limón de pezones azules o el recuerdo en redoma amarilla", con manos de oro propicia "la rosa que enlaza la aroma y la nieve"; su corazón es de azafrán; montará en la racha de una "serpentina quimera", canta con su "río de mármol la ilustre sonata". Sonata, cascada, alas de oro, torrente de trinos, ley de cristal, racimo de nieve del cisne, pámpano jádico, nácar marino, Tritón encefálico, bocina del ciclo, rosa que canta en el fuego, luz torrencial 
de zafiro, cuna de las esmeraldas, cítara eterna: he aquî la letanía del Modernismo, las voces que retratan a Dario y configuran su escuela literaria, su ancestro gongorino y parnasiano, su exotismo aristocrático, su poesía íntegra como una gran vidriera de objetos, seres y nombres preciosos.

La decadencia, ya la conocemos. Darío paseó por cortes y restaurantes de lujo, de París a Madrid, de Madrid a Nueva York a Buenos Aires, movido como el monarca de un museo de cera, conservado en cognac y pasando resplandecientes cartulinas:

... y así lo pasean en su levitón de tristeza lejos del amor, entregado al cognac de los filibusteros. Es como un inmenso y sonámbulo perro que trota y cojea por salas repletas de conmovedora ignorancia...

...y Francisca Sánchez no reza a los piez amatillos de su

[minotauro...

Neruda ha reconocido a Darío, padre de poetas; no lo idealiza, lo ve en gloria y majestad tanto como en la miseria de su espectacular decadencia.

Sigue $L_{a}$ barcarola describiendo un instante de íntima comunión del poeta con los misterios de la noche $y$, por contraste, con la razón del día, los polos del hombre que va y viene sin obtener respuestas, apenas asombrado, o maravillado, o emocionado ante el misterio que es él mismo. Observa y juźga "la misteriosa consigna del viaje de los universos" y pregunta:

Por qué me disputan la tierra y la sombra y a qué materiales que aún no conozco están destinados mis huesos y la destrucción de mi sangre?

Otra incógnita surge al volcarse el mundo sobre su eje de estrellas: la secreta preparación del día, el paso de los hombres, la actividad de la materia entre dos noches oscilando como batientes de una puerta escondida:

el día prepara sus huevos de cro, sus firmes panales dispone en el útero oscuro del mundo y en la claridad, sobre el mar despertó la ballena bestial $y$ pintó con un negro pincel. una línea nocturna en la aurora que sale del mar temblorosa. 
El acento y la intención cósmica de este poema, más que reflejos de la imagen de Darío, son reafirmaciones de un tema whitmaniano constante a través de Song of Myself.

11. La forma del Séptimo Episodio, "Lord Cochrane de Chile", semeja la de Fulgor y muerte de Jodquín Murieta: intento de cantata que se inicia con la voz de Lord Cochrane en una truculenta enumeración de miembros cortados y su equivalencia en libras esterlinas de las sinecuras de los lores ingleses. Cochrane es, entonces, un rebelde que enrostra a sus pares la desvergüenza del sistema autocrático. Luego se alude a un proceso, una condena, el exilio. Llamado por el Gobierno de Chile, Lord Cochrane se convierte en el primer Almirante de la nueva república en su lucha contra la monarquía española. Hay un "Coro de los mares oprimidos", último intento de dar forma dialogada al poema. Es posible que Neruda haya pensado en un espectáculo épico alrededor de la imagen de Cochrane. Prefirió el poema. Canta la valentía y sabiduría del marino en combate - Callao y Valdivia-, su visión de líder, los triunfos, y su regreso a la patria lejana. Neruda exhalta a un héroe a quien no se ha hecho justicia en la historia de Inglaterra.

El poema se sostiene concretamente en imágenes de Chile y del combatiente: "envuelta en ropaje de nieve como un monumento que aún no inauguran", "mineral y marina es mi patria como una figura de proa", "mi patria es la espada de piedra de las cordilleras andinas"; de Cochrane se dice: "semblante delgado de halcón oceánico", "hombre que huyó de la niebla", "los ojos de Cochrane navegan, indagan, acechan", "caballero intranquilo de la libertad y las olas..."

Bosque, pájaros, lago, son los elementos de La barcarola que sigue. Simetría clara, transparente, sonora, del bosque. Nobles imágenes gongorinas en el vuelo de los pájaros. Luz y sonido es el lago. La naturaleza chilena se humaniza en un encadenamiento de imágenes barrocamente elaboradas: los pájaros son "delgada cascada de música silvestre", "hilo que el agua, la flauta y el platino - mantienen en el aire, de rama en rama pura - es el juego simétrico de la tierra que canta", "círculo del mundo convertido en pureza". Hojas, maderos, musgo, helechos, y voces sureñas se entrelazan para recrear la patria: "ramajes leprosos como estatuas de exploradores muertos", "copa del ulmo", "el follaje de los avellanos cortados por tijeretazos celestes", "las gigantescas peinetas hirsutas de las araucarias", "colosales helechos que mueven la esmeralda fría de sus abanicos", maitenes, copihues, canelos. De súbito, el poema 
se decanta y destila gota a gota en un ejercicio de sonidos sobre un modelo de misteriosa sonoridad: Pucatrihue. Desgrínanse las vocales y consonantes en curiosas aliteraciones de eles, haches y eses:

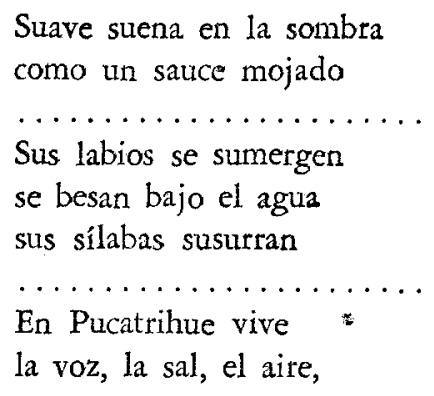

Sonidos de la voz confusa del lago, conversaciones revueltas en el tiempo atesorado por el agua. $Y$ un nombre que lleva consigo algo más que consonantes $y$ vocales:

Ay, Delia, mis raíces están en Pucatrihue.

12. "Artigas", Octavo Episodio, es otro ejercicio en el uso de alite. raciones y juegos de voces, homenaje lírico a un nombre melódico, a una nación transfigurada en sonidos: "Uruguay, Uruguay, uruguayan los cantos del río uruguayo". Es un grito, un nombre de pájaro, idioma del agua, sílaba de una cascada, Uruguay es "la ropa tendida en el oro de un día de viento". En los dedos de Neruda, Uruguay es una caja de música que examina y toca por todos los costados, haciéndola sonar y resonar, buscando los íntimos mecanismos de sus úes y los vinculos de la voz con la imagen sombría del héroe Attigas, "jinete del escalofrío", "centauro de la polvareda", soldado de "poncho estrellado".

No es este poema una operación mayor en el itinerario de la barcarola. Se trata de una despedida; de las líneas que se dejan a la carrera antes de la partida. Se cumple una deuda:

Y si Pablo Neruda, el cronista de todas las cosas te debía Uruguay este canto, este cuento, esta miga de espiga, este Artigas, no falté a mis deberes... 
Las palabras se imponen al fin:

me acendré hasta sentirme deudor de tu olor y tu amor. $\mathrm{Y}$ tal vez está escrito el rumor que tu amor $\mathrm{y}$ tu olor me otorgaron...

Sigue La burcarola con un "Solo de sol" y el odio, algún odio repetido, acechante, ha quedado definitivamente atrás; entra, en cambio, al mediodía de la dicha ("el sol como un pez palpitante en el cielo"), centro, corola, semilla de vida, La barcarola es el amor que "navega en la luz conquistada", vencedora de sombras, barca sintesis que aúna las corrientes del día y la noche y va descubriendo el secreto detrás de su cola y estela. Se transparenta la sal, se juntan tierra y mar, el color del mundo es el color del amor, Iuz y sombra; Matilde, la estatua del sur en la lluvia; Neruda, oscurecido por su "resplandor cereal"; la vida, la apasionada verdad, tiene la forma de la fruta, la unidad de los hemisferios.

13. Algo anda mal en nuestra aporreada versión de un continente: Un sujeto bastante torvo, compadecible o despreciable, que aprendió el arte de vivir no viviendo, escamoteador de poco rango llamado Chivilcoy, es el antihéroe del Décimo Episodio. Se define con desfachatez:

Yo cambio de rumbo, de empleo, de bar y de barco, de pelo de tienda y mujer, lancinante, exprofeso no existo, tal vez soy mexibiano, argentuayo, bolivio, caribián, panamante, colomvenechilenomalteco:

aprendí en los mercados a vender y comprar caminando: me inscribí en los partidos dispares y cambié de camisa...

Es el ladino que en Chile llamamos vivaracho, el sujeto de los mil trucos, petardista de mala muerte, el hombre del negociado que cambia a su madre por un automóvil y vende su casa (que no es suya) con la mujer y los hijos adentro. Pájaro de poco vuelo que, para colmo de desgracias, se adueñó del fisco y regenta la burocracia de nuestros países de thedio pelo; gestor y abogado de compañías yanquis, empeña la patria, cobra intereses, vende banderas para barcos piratas, firma tratados de cien años. Chivilcoy es el inventor del status quo: de Cuba lo sacaron a patadas, de Chile y del Perú se arranca. "No tengo comienzo ni fin", dice, y con desplante graba su moraleja: "mi moraleja consiste en un pescado frito". Tiene razón. Decididamente está frito.

$Y$, al seguir La barcarola, es para dejarnos oír la voz de la mayoría 
silenciosa, que eternamente pide algo y no sabe "a quien pedírselo". Pide por su patria, Chilito, donde "los volcanes ertantes de las edades ante. riores - se juntaron como carpas de circo", tierra terremoteada, y pide por los niños del invierno, pide y pide. Tal vez Neruda siente que en esta voz va gran parte de la suya, no sin esperanzas, al contrario:

En el pedir no hay engaño.

porque la vida entera me la pasé pidiendo

para que los demás alguna vez pudieran vivit tranquilos.

14. Los dos ulltimos episodios versan sobre seres sin nombre propio: el astronauta y las máscaras marinas.

El astronauta es el viajero que busca "con tristeza la identidad, la historia" y no encuentra sino silencio mientras perfora masas de un universo sin consistencia, montañas de harina, cavernas vacías donde gotea eternamente la luz. La visión selenita vive en imágenes surrealistas: "iguanas muertas tal vez eran los vestigios del polvo", "y era toda la estrella aquella como una antigua mariposa", "me perdí por las galerías del sol tal vez derribado - o en la luna sin corazón con sus espejos carcomidos", "poco a poco el silencio me hizo un Robinson asustadizo sin ropa, pero sin nombre", "el planeta me descolgó de mi lengua - y erré sin idioma, oscuro, por las arenas del silencio", "fui enterrado por un cauce silencioso - por un gran río de esmeraldas que no sabian cantar".

Es un poema barroco, gongorino, de armazón abstracta, poema que depende del silencio para hacerse oír, y cuyo vocabulario sugiere un mundo sin materia nombrando materias en un contexto que las niega: huesos del silencio carbonizado - cenizas celestiales - vestigios del polvo - las piedras del frío - luna sin corazón - espejos carcomidos - arenas del silencio.

Sigue La barcarola con una ambiciosa lista de ofrecimientos a Matilde. El poeta le ofrece este mundo y el otro en un lenguaje que resplandece con la precisión de sus imágenes y la nitidez ingeniosa de sus juegos de contrastes: "te doy o te niego en la copa del mundo", dice Neruda y procede a enumerar ordenadamente una colección de imágenes que va desde la Isla de Pascua ("aquella república de tristes estatuas que lloran al lado del mundo del mar") al mundo de las abejas, las hojas, las piedras, el trigo, las arañas, las flores, los trenes y zapatos, lápices y pájaros. Algunas imágenes hacen pensar en el Neruda del año veinte: "el peso nupcial de la abeja cargada de oro oloroso", "la colección de las hojas de todo el otoño en los bosques", "un trono de mimbre tejido por las ele. 
gantes arañas de Angol", "un par de zapatos cortados en piedra de luna", "el lápiz marino capaz de escribir en la ola".

Parece un renacimiento de la imaginería creacionista; un volador de luces y palabras alumbra al poema bajo el ojo avizor de Neruda, para concluir con ironia:

y lo que tú quieras y lo que no quieras te doy y te niego porque las palabras estallan abriendo el castillo, $y$ cerramos los ojos.

15. El último episodio, "La máscava marina", toca un tema tradicional en la poesia de Neruda: la fusión de mar y máscara como símbolo del tiempo inmóvil en su eterno pasar, y su acción sobre el hombre convertido en ciego testigo de sus propias edades. Neruda se acerca a este tema armado de sibilantes aliteraciones para sugerir la profundidad del mis. terio oceánico:

Resbala en la húmeda suma la luna

sorteando la sala con su susurrante salida

Se encrespa el verso con antiguos gongorismos:

Y el sol de la aurora aurorea en la sopa del mar

la sopa del mar sopa negra pasó por la sombra parece que se abre una caja si sale la aurora como un abanico cerrado es el sol en su cielo salió de la caja la luz de la caja de jacarandá

Jitanjáforas les llamaba Alfonso Reyes a estos ejercicios lingüísticos. Neruda los usa en camino hacia algo más substancial: la identificación de la estatua de proa con la condición del marinero en el barco de la vida. La fraseología conversacional de índole surrealista le sirve de puente para completar la transición:

abanico era entonces encima esplendor era fría esperanza y yo déle que déle al navio.. .

De aquí emerge la máscara marina mirando sin ojos el movimiento del mundo, marcado por soles que ascienden como uvas hasta el cenitracimo; la noche, el día, el mediodía, son los vaivenes de la barcarola: "Yo vivo en el gran movimiento del orbe en la nave". La humanidad suma y sigue, participa del hervor cósmico, sin mover los ojos, ni cantar, 
ni soñar, fuerza dentro de otra fuerza mayor, empujada en la marea hacia un puerto inalcanzable:

el mar alcohol del planeta la rosa que hierve y el agua que arde yo sigo yo sumo.

El hervor del mar, la actividad de la materia, rodean "la desventurada cabeza en la eterna interperie", pero no la vencen; la gastan, mas se mantiene impertérrita en el movimiento de la eterna barcarola, partícipe de su condición cósmica: "Soy parte incesante de la dirección de la esencia".

La estatua de proa vence los desdeñables peligros del armador vendido, la minucia de los merdaderes en mares, puertos y ciudades, avanza sin rumbo, pero liberada, por encima de corsarios y guerreros, intocada por los cataclismos, confundida ya en sus esencias con el mar, hablando, por fin, con la voz del poeta:

yo me incorporo al camino mis ojos no saben llorat soy sólo una forma en la luz una vértebra de la alegoría.

Los mascarones de proa habitan con Neruda en Isla Negra, son mitos del mar, amarrados a paredes de estuco y madera, forcejeando eternamente con la casa, queriendo llevársela, pero detenidos, afrontando las neblinas, las espumas que suben del roquerío, sujetos como bellos monstruos del tiempo por las riendas del poeta que sabe manejar su movimiento invisible.

16. La barcarola concluye con un "Solo de sal", y no es este título un juego de palabras: sal es término de vida, sufrimiento, y purificación en el idioma de Neruda. La baratrola viene, entonces, desde un antiguo Vietnam donde el poeta vivió en 1928, en un viaje de soledad y angustia que, paulatinamente, se convierte en otro de amor y resistencia a la muerte. Maldice Neruda a los enemigos de la vida, los gordos masticadores de niños, ases del napalm, capitalistas del irust mortuorio, cuyas pompas fúnebres van por los cielos con motores a chorro. Dejan caer sus bombas sobre la barcarola que odian, pero la pequeña barca de la humanidad es más resistente que ellos, más fuerte y veloz. Atraviesa noches de fanatismo y crueldad a través de las edades, salpica de sangre a los amantes, pero no importa:

Amor mío, a lo largo de la costa larga de un pétalo a otro la tierra construye el aroma 
y ya el estandarte de la primavera proclama nuestra eternidad no por breve menos lacerante.

Si nunca la nave en su imperio regresa con dedos intactos si la barcarola seguía su rumbo en el trueno marino y si tu cintura dorada vertió su belleza en mis manos aquí sometemos en este regreso del mar, el destino, y sin más examen cumplimos con la llamarada.

La barcarola termina, en consecuencia, con una elocuente defensa de la vida, contra la muerte:

Es la hora, amor mío, de apartar esta rosa sombría, cerrar las estrellas, enterrar la ceniza en la tierra:

y en la insurrección de la luz, despertar con los que despertaron

o seguïr en el sueño alcanzando la otra orilla del mar que no tiene otra orilla.

Los amantes sortearon las aguas difíciles de la pasión recriminada, navegaron por ciudades conocidas y desconocidas, visitaron los héroes de la leyenda y las suaves playas de los viejos amigos, sobrevivieron guerras y temblores, se deslizan ahora por un mar sin orilla; las mitades del mundo se han juntado y mar, tierra, estrellas y barca son un solo gran círculo que gira para siempre en el amor consumado de Pablo y Matilde, los navegantes felices.

Fernando Alegría 